\title{
Microbiology of root crops, edible corms, tubers, bulbs, and rhizomes: An endobacteriological study
}

\author{
Jack R. Edelman ${ }^{1}$, Yue J. Lin ${ }^{2}$ \\ ${ }^{1}$ Department of Science, Borough of Manhattan Community College, City University of New York, New York, U.S.A. \\ ${ }^{2}$ Department of Biological Sciences, Saint John's University, Jamaica, U.S.A.
}

\section{Email address:}

thechromosomekid@37.com (J. R. Edelman), themadprofessor47@hotmail.com (J. R. Edelman)

\section{To site this article:}

Jack R. Edelman, Yue J. Lin. Microbiology of Root Crops, Edible Corms, Tubers, Bulbs, and Rhizomes: An Endobacteriological Study. International Journal of Nutrition and Food Sciences. Vol. 3, No. 2, 2014, pp. 69-72. doi: 10.11648/j.ijnfs.20140302.18

\begin{abstract}
A variety of root crops, corms, tubers, and rhizomes commonly eaten and available in public markets were tested for the presence and identification of bacteria in their inner flesh. Bacteria were grown on agar slants and identified by DNA sequence analysis. Among foods tested were various radishes, onions, shallots, leeks, yams, parsnips, turnips, carrots, potatoes, ginger, garlic, parsnips, beets, horse radish, kohl-rabi, and less well-known crops such as yucca/cassava, celery root/celeriac, jicama, taro, lotus, water chestnut, Chinese/Korean yam (nagaimo), edible burdock (golden gobo), batata, root parsley, and yautia (malanga). Examples of the bacterial genera identified were, among others, species of Arthrobacter, Pantoea, Bacillus, Pseudomonas, Staphylococcus, Microbacterium, Stenotrophomonas, Rahnella, Rhodococcus, Paenibacillus, Oerskovia, Gordonia, and Leclercia. While these species are probably present in harmless numbers, their presence may indicate that the inner flesh of these crops should be studied more extensively. Crops that are boiled, fried, baked or otherwise cooked may obviously not be a health hazard, but some of these vegetables are eaten raw or only lightly cooked and may possibly merit further study for possible health implications. Tubers that were very proficient in producing new shoots, such as potato and the Chinese/Korean yam (nagaimo) were found to contain inner flesh free of bacteria and seemed to be resistant to rotting; this may imply that these tubers have antimicrobial properties.
\end{abstract}

Keywords: Root Crops, Vegetables, Corms, Tubers, Bulbs, Rhizomes, Bacteria, Endobacteriology

\section{Introduction}

Our recent study of a number of fruits in the Cucumber family (Cucurbitaceae) revealed that many contain various species of bacteria in their inner flesh/pulp as well as on their surface, especially when netting is present on their rinds, such as many melons and cantaloupes (Edelman and Lin, 2011). Fruits that have warts on their surfaces/rinds also often contained bacteria inside the warts and throughout their inner flesh, such as bitter melon (Momordica charantia) and various kinds of gourds (Lagenaria siceraria). Cucumbers and commercially pickled cucumbers likewise usually contained various bacterial species in their inner flesh/pulp. While the presence of these bacterial species do not necessarily impose health risks with consumption of such fruits, the findings indicate that more research is needed in this field. We referred to the study bacteria on the fruit surface as "topobacteriology" and the study of bacteria of the inner flesh/pulp as "endobacteriology", respectively (Edelman and Lin, 2011). The findings of that study prompted us to continue the study of bacteria found in foods by examining the presence and identification of bacteria in root crops, including edible roots, tubers, corms, bulbs, and rhizomes. Since these vegetables are constantly in contact with the soil, we decided not to study the presence of surface bacteria (topobacteriology) since they would obviously be expected to be present (but can be removed with efficient washing). However, we decided to investigate whether bacteria are present in their inner flesh/pulp, (endobacteriology), since this region cannot be washed prior to consumption, and since many of these root crops are eaten raw, or added to salads, without prior cooking. The results of our investigation are described in this report.

\section{Materials and Methods}

Edible root crops, tubers, bulbs, corms, and rhizomes of various vegetables were purchased from local markets, and washed well with soapy water on their outer surface, rinsed, 
and allowed to dry. The surfaces were briefly wiped with commercial household bleach (hypochlorite), rinsed well, blotted dry, rinsed several times again and allowed to air dry. They were then cut open with sterile cutlery and a sterile cotton tip applicator was swabbed into the inside flesh/pulp. A cotton tip applicator was then used to streak the surface of an agar slant which contained tryptic soy agar, using the same method which we reported previously with various fruits of the Cucurbitaceae family (Edelman and Lin, 2011). Agar slants were then incubated at room temperature and/or at 37 degrees C. If any colonies appeared within several days, the agar slants were shipped to a professional laboratory for bacterial identification using DNA sequence analysis (MICROCHECK LAB, 142 Gould Road, Northfield, Vermont, 05663, USA, www.microcheck.com). This facility is currently under the direction of ATS Labs, Inc., 1285 Corporate Center Drive, Suite 110, Eagan, Minnesota, 55121, U.S.A., (www.atslabs.com).

\section{Results, Discussion and Conclusions}

Results are shown in Table 1. Most food specimens tested, but not all, did indeed contain live bacteria, whereas a few food specimens were sterile. Experiments were repeated several times to ascertain that the bacterial growth was indeed from inhabitants of the inner flesh/pulp rather than false positives due to possible contamination during the procedure.

Table 1. Bacterial species identified within the inner flesh/pulp region of edible below ground vegetables (root crops, tubers, bulbs, corms, or rhizomes).

\begin{tabular}{|c|c|c|}
\hline Vegetable & Region & Species identified \\
\hline $\begin{array}{l}\text { Onion } \\
\text { (Allium cepa) }\end{array}$ & Bulb & $\begin{array}{l}\text { Staphylococcus warneri } \\
\text { Pseudomonas } \\
\text { aeruginosa }\end{array}$ \\
\hline $\begin{array}{l}\text { Yucca (cassava) } \\
\text { (Manihot esculenta) }\end{array}$ & Corm & Bacillus niacini \\
\hline $\begin{array}{l}\text { Ginger } \\
\text { (Zingiber officinale) }\end{array}$ & Rhizome & $\begin{array}{l}\text { Pantoea sp./Pantoea } \\
\text { dispersa }\end{array}$ \\
\hline Lotus 'root' & Rhizome & $\begin{array}{l}\text { Arthrobacter } \\
\text { sp./Arthrobacter } \\
\text { nicotinae }\end{array}$ \\
\hline (Nelumbo nucifera) & & Leclercia adecarboxylata \\
\hline $\begin{array}{l}\text { White Daikon Radish } \\
\text { (Raphanus sativus var. } \\
\text { longipinnatus) }\end{array}$ & Root & $\begin{array}{l}\text { Pantoea agglomerans } \\
\text { ATCC }=27155\end{array}$ \\
\hline $\begin{array}{l}\text { Green Daikon Radish } \\
\text { (Raphanus sativus var. long }\end{array}$ & $\begin{array}{c}\text { Root } \\
\text { nnatus) }\end{array}$ & (sterile) \\
\hline $\begin{array}{l}\text { Red Radish (Cherry Belle) } \\
\text { (Raphanus sativus var. Cher }\end{array}$ & $\begin{array}{l}\text { Root } \\
\text { Belle) }\end{array}$ & (sterile) \\
\hline $\begin{array}{l}\text { Celeriac/Knob Celery Root } \\
\text { (Apium graveolens }\end{array}$ & Root & $\begin{array}{l}\text { Pseudomonas veronii } \\
\text { Pseudomonas fulva }\end{array}$ \\
\hline
\end{tabular}

\begin{tabular}{|c|c|c|}
\hline Vegetable & Region & Species identified \\
\hline var. rapaceum) & & $\begin{array}{l}\text { Microbacterium } \\
\text { liquifaciens }\end{array}$ \\
\hline $\begin{array}{l}\text { Water Chestnut } \\
\text { (Eleocharis dulcis) }\end{array}$ & Corm & Rahnella aquatilis \\
\hline $\begin{array}{l}\text { Chinese/Korean/Asian } \\
\text { Yam/Japanese Mountain } \\
\text { Yam/Nagaimo } \\
\text { (Dioscorea opposita) }\end{array}$ & tuber & (sterile) \\
\hline $\begin{array}{l}\text { Edible Burdock Root/Gobo } \\
\text { (Arctium lappa) }\end{array}$ & root & $\begin{array}{l}\text { Stenotrophomonas } \\
\text { maltophilia } \\
\text { Pseudomonas fulva }\end{array}$ \\
\hline 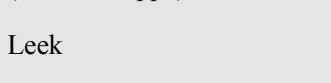 & $\begin{array}{l}\text { leaf sheath } \\
\text { bundle }\end{array}$ & Rahnella aquatilis \\
\hline $\begin{array}{l}\text { (Allium ampleoprasum var. } \\
\text { porrum, Allium porrum) }\end{array}$ & & $\begin{array}{l}\text { Pseudomonas tolaasii } \\
\text { Pantoea agglomerans } \\
\text { ATCC }=27155\end{array}$ \\
\hline $\begin{array}{l}\text { Orange Sweet Potato/Yam } \\
\text { (Ipomoea batatas) }\end{array}$ & $\begin{array}{l}\text { tuberous } \\
\text { root }\end{array}$ & (sterile) \\
\hline $\begin{array}{l}\text { White Sweet Potato } \\
\text { (Batatas, }\end{array}$ & & \\
\hline $\begin{array}{l}\text { Boniato, Camote) } \\
\text { (Ipomoea batatas) }\end{array}$ & $\begin{array}{l}\text { tuberous } \\
\text { root }\end{array}$ & $\begin{array}{l}\text { Bacillus pumilus / } \\
\text { Bacillus safensis }\end{array}$ \\
\hline $\begin{array}{l}\text { Jicama root } \\
\text { (Pachyrhizus erosos) }\end{array}$ & $\begin{array}{l}\text { tuberous } \\
\text { root }\end{array}$ & $\begin{array}{l}\text { Pantoea agglomerans } \\
\text { ATTC }=27155\end{array}$ \\
\hline Taro & corm & Oerskovia enterophila \\
\hline (Colocasia esculenta) & & $\begin{array}{l}\text { Microbacterium } \\
\text { flavescens }\end{array}$ \\
\hline $\begin{array}{l}\text { Root Parsley } \\
\text { (Petroselinum crispum tuber } \\
\text { Petroselinum hortense) }\end{array}$ & root & $\begin{array}{l}\text { Microbacterium lutedum } \\
\text { Pantoea agglomerans } \\
\text { ATCC }=27155\end{array}$ \\
\hline $\begin{array}{l}\text { Black Spanish Radish } \\
\text { (Raphanus sativus var. } \\
\text { niger) }\end{array}$ & root & $\begin{array}{l}\text { Pseudomonas cedrina } \\
\text { Stenotrophomonas } \\
\text { rhizophila } \\
\text { Rhodococcus } \\
\text { baikonurensis / R. } \\
\text { globerulus } \\
\text { ATCC }=25714\end{array}$ \\
\hline Yautia (Malanga, Tannia, & & \\
\hline $\begin{array}{l}\text { Tannier, Cocoyam) } \\
\text { (Xanthosoma spp.) }\end{array}$ & corm & $\begin{array}{l}\text { Bacillus barbaricus } \\
\text { Paenibacillus apiarius } \\
\text { Gordonia terrae } \\
\text { Pseudomonas monteilii }\end{array}$ \\
\hline $\begin{array}{l}\text { Parsnip } \\
\text { (Pastinaca sativa) }\end{array}$ & root & (sterile) \\
\hline $\begin{array}{l}\text { Red Beet } \\
\text { (Beta vulgaris) }\end{array}$ & root & (sterile) \\
\hline $\begin{array}{l}\text { Turnip } \\
\text { (Brassica rapa var. rapa) }\end{array}$ & root & (sterile) \\
\hline $\begin{array}{l}\text { Carrot } \\
\text { (Daucus carota) }\end{array}$ & root & (sterile) \\
\hline
\end{tabular}




\begin{tabular}{lll}
\hline Vegetable & Region & Species identified \\
\hline $\begin{array}{l}\text { Potato } \\
\text { (Solanum tuberosum) }\end{array}$ & tuber & (sterile) \\
$\begin{array}{l}\text { Shallot } \\
\text { (Allium cepa var. }\end{array}$ & bulb & (sterile) \\
$\begin{array}{l}\text { aggregatum) } \\
\text { Garlic }\end{array}$ & & \\
(Allium sativum) & bulb & (sterile) \\
Kohlrabi & swollen & \\
(Brassica oleracea) & stem base & (sterile) \\
Horseradish* & & \\
(Armoracia rusticana, & root & $\begin{array}{l}\text { Rahnella aquatilis } \\
\text { Cochlearia armoracia) }\end{array}$ \\
Jerusalem Artichoke, & & $\begin{array}{l}\text { Stenotrophomonas } \\
\text { maltophilia }\end{array}$ \\
(Sunchoke, & & \\
Topinambur) & & \\
(Helianthus tuberosus) & & Pseudomonas marginalis \\
& & Pseudomonas fulva \\
& & $\begin{array}{l}\text { Pantoea agglomerans } \\
\text { ATCC=27155 }\end{array}$ \\
\hline
\end{tabular}

*Commercial, bottled horseradish preparations, such as horseradish sauce and other condiments containing horseradish, also contained bacteria, even when salt, vinegar/acetic acid, spices, preservatives, and other substances were added. This is most likely due to the presence, survival and resilience of bacterial endospores.

As can be seen from Table 1, many, if not most root crops tested were found to contain various species of bacteria. These findings do not necessarily imply that such bacteria pose a health risk to people who consume these crops, since humans have been cultivating and consuming these vegetables for thousands of years. These findings do, however, indicate that more research is needed in this field--“endobacteriology”---of various root crops (roots, tubers, corms, bulbs, rhizomes, etc.). According to Bergey's Manual of Determinative Bacteriology, most, if not all, of the bacterial species we have identified in this report in the inner flesh/pulp of these various root crops are widely distributed in nature, in soil, water, food, sewerage, insects, and in general, the environment (Holt et al., 2000). Some of these vegetables are cooked before eating-boiling, frying, steaming, baking---- so that any or most indigenous bacteria are likely destroyed, minimizing or eliminating any health risks present. Some such vegetables, however, are eaten raw or added to salads and other foods, so that any possible health risks remain. The Jerusalem artichoke is an example of a vegetable that can be eaten raw or cooked, so eating this crop raw may, at least potentially, be hazardous. The longer the tubers remain in storage, the higher the bacterial count, even if stored under refrigeration. This is also true of vegetables such as onions and shallots, which may be eaten raw or cooked, while certain other crops are usually eaten raw, such as ginger, red and black radishes and daikons, Jicama, and horse radish. Since these crops are in direct contact with the soil during their growth and cultivation, it is certainly not surprising that bacteria would be found on their surfaces, but this study indicates that various bacteria are present in their inner flesh/pulp as well. This is particularly significant when and if crops are injured or damaged during their growth or harvesting, where soil and bacteria may enter the wounds directly and survive and multiply in the inner flesh/pulp. However, as shown in this report, even crops that are not injured or damaged often contain bacterial species in their inner flesh/pulp, and washing the rind/outer surface with soapy water and household bleach had no effect on their presence, indicating that these species naturally reside in the inner flesh/pulp of many such crops (endobacteriology). Interestingly, horseradish endobacteria persist after processing, so that many horseradish-containing products, such as horseradish sauces and condiments, contain living horseradish endobacteria and/or their viable endospores, which persist even when vinegar (acetic acid), salt, various spices and preservatives are added. As we found in our study of fruits of the cucumber (Cucurbitaceae) family (Edelman and Lin, 2011), the subject of endobacteriology is applicable to various root crop vegetables (roots, tubers, corms, bulbs, rhizomes) as well. In our previous study, melons with netted rinds harbored many bacteria, and even after washing with soapy water, viable bacteria remained in the netting (Edelman and Lin, 2011). Our finding that the netting on the rinds of melons and other fruits contains various species of bacteria is of additional importance since today, many households use blenders/homogenizers/food processors to produce fruit and vegetable juices and purees. In some cases. entire fruits/vegetables, including the netted rinds are added to the blender. Our finding that the netting and/or scars on the rinds of melons and other crops contain numerous bacteria may indicate that netted rinds may pose a health hazard if they are added to the blended juice/puree mixture. Among bacterial species found in the netted rinds of various cantaloupes/muskmelons and other melons were, as well as Staphylococcus sciuri rodentium, Streptoverticillium reticulum, Kocuria rhizophila, Photorhabdus luminescens luminescens, Escherichia vulneris, and Pseudomonas chlororaphis, P. aureofaciens, P. aurantiaca Bacillus pumilus, B. subtilis, B. licheniformis, B. megaterium, Flavimonas oryzihabitans, Paenibacillus lentimorbus, among other species. Carlin (2011) reported that bacterial spores in food may arise from soil, feces, animal feeds, food ingredients and the processing facilities themselves. Although the spores themselves might not be dangerous, their germination into vegetative cells may be pathogen-generating. Lopez-Velasco et al.,(2012) reported that melons have been implicated in outbreaks of foodborne illnesses over the past decade. This was especially true of cantaloupes, which were often infected with Salmonella, both on the rinds and in the inner flesh/pulp. According to Fields (1979), bacteria that inhabit the surface of crops while they are cultivated in the soil are referred to as indigenous or autochthonous flora .Roberts et al., (1995) reported that certain species of the Bacillus 
genus have caused episodes of food poisoning. The finding and identification of bacterial species in various root crops, edible corms, bulbs, rhizomes, etc. reported here is not intended to cause a 'scare' or panic among consumers, since humans have been consuming these vegetables for thousands of years, and have obviously built up an immunity/resistance or tolerance to these organisms throughout that period of time Our purpose is merely to inform the public and scientists that these species are inhabitants of these crops, and more research is needed in this field---“"endobacteriology"--, in order to further assess if any health hazards are indeed present amongst consumers, especially amongst those that are immunecompromised or who exhibit poor health/lower resistance to disease. Indeed, our previous findings that the netting on the rinds of various melons harbors many bacterial species and large numbers of them (Edelman and Lin, 2011) is an indication that rinds of melons should not be consumed, and should not be added to blenders/homogenizers/food processors! This is true even if the rinds are washed with soapy water/detergents. In our opinion, this is a field of nutrition that requires further study, as it may have implications in the areas of epidemiology and, in general, world-wide human health!

\section{Acknowledgements}

The authors wish to thank the following colleagues of the Science Department, Borough of Manhattan Community College, City University of New York, for help with equipment and materials needed for this study: Ms. Carmen Rivera, Mr. Robert J. Bauer, and Mr. Owen Myers, College Laboratory Technicians; Professor Christopher Thompson, Professor Owen Myers, and Professor Faisel Adem.

\section{References}

[1] Carlin, F. (2011) Origin of bacterial spores in contaminating foods, Food Microbiology 28:177-182.

[2] Edelman, J.R. and Lin, Y.J. (2011). Microbiology of melons, cucumbers, and squash (Cucurbitaceae) and related fruits. Int'l. J. of Food Science, Technology, \& Nutrition, 5: (No.1), 51-65.

[3] Field, M.L., (1979). Fundamentals of Food Microbiology. AVI Publishing Co., Westport, Connecticut, U.S.A.

[4] Holt, J.G., Krieg, N.R., Sneath, P.H.A., Staley, J.T., and Williams, S.T., (2000). In: Bergey's Manual of Determinative Bacteriology, $9^{\text {th }}$ Edition, Lippincott Williams \& Wilkins, Philadelphia, Pennsylvania, USA.

[5] Lopez-Velasco, G., Sbodio, A., Tomas-Callejas, A., Wei, P., Tan, K.H., and Suslow,T.V., (2012). Assessment of root uptake and systemic vine-transport of Salmonella enterica sv. Typhimurium by melon (Cucumis melo) during field production, Int'l. J. of Food Microbiology, 158:65-72.

[6] Roberts, D., Hooper, W., and Greenwood, M., (1995). Practical Food Microbiology, Second Edition, Public Health Laboratory Service, London, England. 